\title{
Taxonomic composition and feeding habits of Chironomidae in Cerrado streams (Southeast Brazil): impacts of land use changes
}

\author{
Composição taxonômica e hábitos alimentares de Chironomidae em riachos \\ de Cerrado (Sudeste do Brasil): impactos de mudanças no uso-do-solo
}

Victor Satoru Saito ${ }^{1}$ and Alaíde Aparecida Fonseca-Gessner ${ }^{2}$

\author{
${ }^{1}$ Programa de Pós-Graduação em Ecologia e Recursos Naturais, Universidade Federal de São \\ Carlos - UFSCar, Rodovia Washington Luís, km 235, SP-310, CEP 13565-905, São Carlos, SP, Brazil \\ e-mail: victor.saito@gmail.com \\ ${ }^{2}$ Departamento de Hidrobiologia, Centro de Ciências Biológicas e da Saúde, Universidade Federal de São \\ Carlos - UFSCar, Rodovia Washington Luís, km 235, SP-310, CEP 13565-905, São Carlos, SP, Brazil \\ e-mail: gessner@ufscar.br
}

\begin{abstract}
The Chironomidae family is the most abundant and diverse member of the benthic community in streams, yet their identification is still neglected in many papers. It is considered a family tolerant to environmental impacts and with homogeneous feeding habit. Aim: To compare the richness, abundance and taxonomic composition of Chironomidae in Cerrado streams under different land uses as well as the feeding habit differences between genera of reference areas, sugar cane culture and pasture. Methods: We selected seven streams in each land use and sampled six units using Surber sampler. The material was transported live for laboratory processing. Results: Our results showed no significant differences in abundance and richness of Chironomidae among different land use, but we observed greater average values of abundance and richness in streams impacted by pasture. We found a distinct taxonomic composition between reference streams and impacted streams, both sugar cane and pasture. Stenochironomus was the most representative genus in reference areas, while Parametriocnemus was in sugar cane culture and Tanytarsus in pastures. The only statistically different feeding pattern found were between Cerrado streams and sugar cane for plant tissues, reflecting the greater abundance of Stenochironomus in Cerrado and among Cerrado streams and pasture for microalgae. Conclusions: We conclude that the conversion of natural areas in monocultures and pastures directly impact streams by modifying the taxonomic structure of Chironomidae. In contrast we did not observe a clear change in feeding patterns, because in all streams the diet pattern was mostly detritivorous.
\end{abstract}

Keywords: aquatic insects, nonbiting midges, environmental impacts, faunal composition, functional groups.

Resumo: A família Chironomidae é a mais abundante e diversa constituinte da comunidade bentônica em riachos e ainda assim sua identificação é negligenciada em muitos trabalhos. É considerada uma família tolerante aos impactos ambientais e com uma alimentação homogênea. Objetivo: Comparar a riqueza, a abundância e a composição taxonômica de Chironomidae em riachos de Cerrado sob diferentes usos-de-solo, bem como as diferenças alimentares entre os gêneros nos riachos em áreas referência e impactadas pela cultura de cana-de-açúcar e pela pastagem. Métodos: Selecionamos sete riachos para cada uso de solo, nos quais coletamos seis unidades com o amostrador Surber. O material foi transportado vivo para processamento em laboratório. Resultados: Nossos resultados não indicaram diferenças significativas na abundância e na riqueza de Chironomidae entre os riachos dos diferentes usos-de-solo, mas observamos uma abundância média e riqueza média maior em riachos impactados pela pastagem. Nós encontramos composiçốes faunísticas distintas entre os riachos referência e os impactados, tanto pela cana-de-açúcar como pela pastagem. Stenochironomus foi o gênero mais representativo em áreas preservadas, enquanto Parametriocnemus foi na monocultura de cana de açúcar e Tanytarsus na pastagem. As únicas diferenças estatísticas alimentares encontradas foram entre os riachos de Cerrado e de cana-de-açúcar para tecidos vegetais, refletindo a maior abundância de Stenochironomus no Cerrado e, entre os riachos de Cerrado e pastagem para microalgas. Conclusóes: Concluímos que a conversão de áreas conservadas em monoculturas e pastagens impactam diretamente os riachos, modificando a estrutura taxonômica de Chironomidae. Em contrapartida não observamos uma mudança clara nos padróes alimentares, pois em todos os riachos a alimentaçấo foi majoritariamente detritívora.

Palavras-chave: insetos aquáticos, mosquitos, impactos ambientais, composição faunística, grupos funcionais. 


\section{Introduction}

The Chironomidae family is one of the most abundant and diverse group of the benthic fauna in freshwater aquatic ecosystems (Coffman, 1973; Rosenberg and Resh, 1993; Ferrington Junior, 2008) and yet many papers neglect their identification. This occurs for several reasons. First, the lack of taxonomic knowledge about the family in the tropical region led to difficulties in identification. In the State of São Paulo advances were made from the Biota-FAPESP program, training specialists and generating publications (Trivinho-Strixino, 2011). Second, the lack of ecological knowledge led many authors to consider them as a homogeneous group in their environmental responses and food preferences (Cummins and Klug, 1979). Third, permanent slides are required for the identification of genus, making the process slower and expensive.

Among the biological indicators there is a generalization of Chironomidae as tolerant to pollution (Barbour et al., 1996; Tetratech, 2000; see Bonada et al., 2006 for a biomonitoring review). Some genera are remarkably resistant to organic enrichment (e.g. Chironomus), but several studies have reported that environmental responses among species are varied, indicating the need for further studies to establish patterns (Lenat, 1983; Corbi, 2006; Corbi and Trivinho-Strixino, 2008; Sonoda et al., 2009). Chironomidae taxonomists argue that the family has sensitive and tolerant genera, with characteristics that can reflect the panorama of aquatic systems and, therefore, more efforts should be made to study the differences in the faunal compositions of reference and impacted areas (Rosenberg, 1992; Rabeni and Wang, 2001; Corbi and Trivinho-Strixino, 2006; TrivinhoStrixino, 2011).

Due to their abundance in benthic communities, the family becomes important in ecosystem processes (Cummins et al., 2005; Ferrington Junior, 2008), especially in processing and transfer of energy in the food web. A functional measure is to analyze the feeding habits of the organisms, noting which items are more abundant (Cummins and Klug, 1979; Poff et al., 2006; Tomanova et al., 2006). In tropical environments, a general pattern is that these organisms are primarily detritivorous because the decomposition of allochthonous material is performed mainly by the microfauna (Irons et al., 1994; Dudgeon and Wu, 1999; see a review at Boyero et al., 2009). Some recent studies have found exceptions to this pattern (Cheshire et al., 2005; Yule et al., 2009), but in general we expect that the Chironomidae fauna will have a diet based on detritus, reflecting the abundance of this resource.

Understanding the effects of land use changes on ecosystems of tropical streams is of fundamental importance for conservation and management in tropical regions (Boyero et al., 2009). The loss of aquatic biodiversity due to changes in land use is well-known, but studies on the effects on some taxonomic group and ecoregions are still scarce and, as in many other countries, the most attention was given to ecoregions of evergreen formations such as the Atlantic Forest and Amazonia (Stott, 1991; Couceiro et al., 2012). The Cerrado, which is considered the most threatened tropical savanna in the world (Silva and Bates, 2002) and the only savanna biodiversity "hotspot” (Myers et al., 2000), is another important ecosystem. Additionally, Brazilian Cerrado streams have distinct aquatic fauna with unique structuring patterns that are subject to different abiotic filters than evergreen formations (Wantzen, 2003; Bispo et al., 2006; Saito and Mazão, 2012).

Thus, our goal was to compare the richness, abundance and taxonomic composition of Chironomidae in Cerrado streams in areas under different land uses as well as the dietary differences between them, and link these differences to the impacts caused by the sugar cane culture and pasture.

\section{Material and Methods}

\subsection{Study area}

We developed our work in the sedimentary basin of São Paulo State (Brazil) (Figure 1), an ecoregion dominated by Cerrado vegetation (Durigan et al., 2007) that is composed of trees and C4 grasses that grow in acid soils rich in aluminum (Durigan et al., 2007). The climate is Köppen's Cwa, with dry winters and hot summers $\left(>22^{\circ} \mathrm{C}\right)$. The main environmental impact in the region is urban growth as this is the most densely populated state in Brazil, with 166 inhabitants $/ \mathrm{km}^{2}$ (IBGE, 2011). Additionally, the study region Cerrado has less than $6 \%$ of its original area protected by law (Silva and Bates, 2002), and it is located on a plateau that favored the expansion of sugarcane monocultures and pastures.

We selected 21 streams of 1 st and 2nd orders, seven in each land use (Cerrado vegetation, pasture and sugar cane culture). The preserved Cerrado streams, recognized here as reference condition, were placed in areas minimally disturbed anthropically 


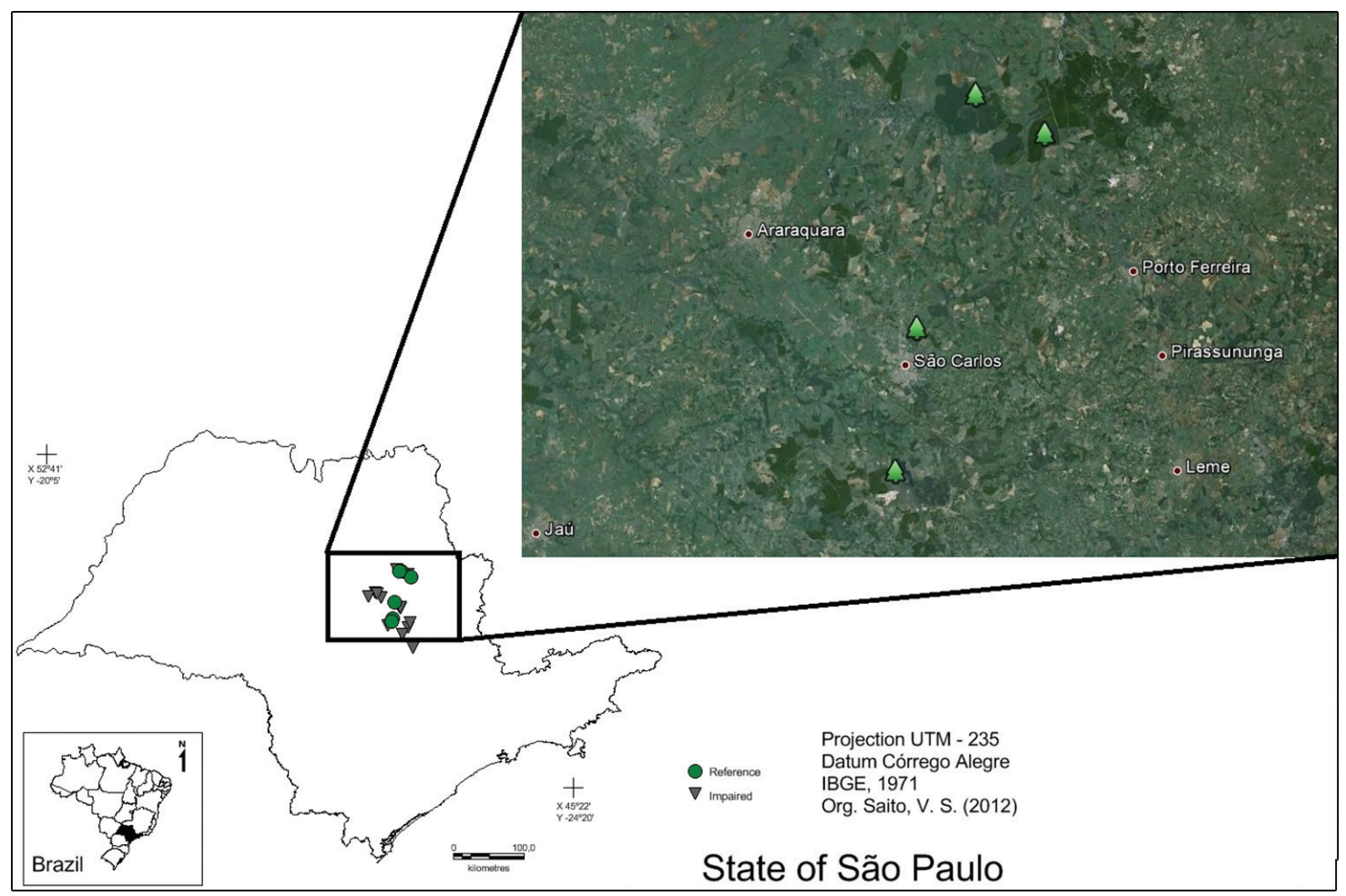

Figure 1. Chironomidae sampling sites in Cerrado streams in the State of São Paulo (Southeast Brazil).

(Bailey et al., 2004; Stoddard et al., 2006), in protected areas with large preserved vegetation adjacent to the stream. These streams are located in the Ecological Station of Jataí (municipality of Luis Antonio), Ecological Station of Itirapina (municipality of Itirapina) Vassununga State Park (municipality of Santa Rita do Passa Quatro) and also in a Cerrado located in São Carlos (Figure 1) (Table 1). And the impacted streams are located in regions completely surrounded by pastures or monoculture of sugar cane where the original vegetation was the Cerrado.

\subsection{Sampling and identification of Chironomidae larvae}

Chironomids were sampled in the dry season (May to August) of 2011. Following the protocol established by Suriano et al. (2010), we selected 100 meter-long stretches of stream and took six samples using a Surber sampler with an area of $30 \times 30$ centimeters (total of $54 \mathrm{~m}^{2}$ per stream) and a mesh opening of $250 \mu \mathrm{m}$. Additionally, for 30 seconds we scanned with a D net to sample microhabitats where a Surber sampler is hard to use. All of the collected material was transported in vivo for laboratory processing. The material of each stream was processed in a maximum of two days after sampling.
Table 1. Table with geographical coordinates of sampled streams (Southeast Brazil), separated by the predominated land use.

\begin{tabular}{ccc}
\hline Land use & Latitude & Longitude \\
\hline Reference & $-21.583896^{\circ}$ & $-47.765006^{\circ}$ \\
Reference & $-21.581458^{\circ}$ & $-47.792062^{\circ}$ \\
Reference & $-22.192501^{\circ}$ & $-47.897231^{\circ}$ \\
Reference & $-22.215833^{\circ}$ & $-47.908611^{\circ}$ \\
Reference & $-22.225000^{\circ}$ & $-47.900000^{\circ}$ \\
Reference & $-21.975833^{\circ}$ & $-47.870278^{\circ}$ \\
Reference & $-21.649444^{\circ}$ & $-47.640278^{\circ}$ \\
Sugar cane & $-21.553889^{\circ}$ & $-47.835833^{\circ}$ \\
Sugar cane & $-21.617222^{\circ}$ & $-47.677500^{\circ}$ \\
Sugar cane & $-21.848889^{\circ}$ & $-48.136111^{\circ}$ \\
Sugar cane & $-21.910556^{\circ}$ & $-48.048056^{\circ}$ \\
Sugar cane & $-21.906944^{\circ}$ & $-48.224722^{\circ}$ \\
Sugar cane & $-22.564167^{\circ}$ & $-47.614167^{\circ}$ \\
Sugar cane & $-22.867500^{\circ}$ & $-48.110278^{\circ}$ \\
Pasture & $-22.303333^{\circ}$ & $-47.670556^{\circ}$ \\
Pasture & $-22.238611^{\circ}$ & $-47.652500^{\circ}$ \\
Pasture & $-22.274444^{\circ}$ & $-47.962500^{\circ}$ \\
Pasture & $-22.038282^{\circ}$ & $-47.783107^{\circ}$ \\
Pasture & $-22.390556^{\circ}$ & $-47.752778^{\circ}$ \\
Pasture & $-22.042411^{\circ}$ & $-47.784611^{\circ}$ \\
Pasture & $-22.051756^{\circ}$ & $-47.788139^{\circ}$ \\
\hline & & \\
\hline
\end{tabular}


Chironomidae larvae were sorted live on transiluminated trays and fixed in etanol $70 \%$. The organisms were mounted on slides and identified to genus level with the aid of a taxonomic key (Trivinho-Strixino, 2011).

\subsection{Data analysis}

\subsubsection{Richness and abundance}

Box-and-whiskers plots and Kruskal-Wallis tests were used to verify if groups differed in total richness and abundance.

\subsubsection{Faunal composition}

A PERMANOVA was used to identify differences in faunal composition among reference sites, sites impacted by sugar cane, and sites impacted by pasture in the Cerrado. In this analysis permutations of the observations are made and result in a distribution of the $\mathrm{F}$ statistic (Anderson, 2001). The F value computed is then compared with the distribution and tested for its significance. We used 1,000 permutations, significance level of 0.05 and the Bray-Curtis dissimilarity index.

To graphically visualize the dissimilarity between groups of streams a multidimensional scaling (MDS) was used using the Bray-Curtis index. A SIMPER analysis was used to identify the genera that contribute the most to the dissimilarity between land uses and also observe the relative abundance of genera.

\subsubsection{Characterization of genera feeding habits (Gfh)}

We analyzed the gut content of each genus to characterize the feeding habits and separate food into five categories: detritus, microalgae, macroalgae, animal and plant tissues. The foreguts of 10 individuals per taxa were removed by dissection, mounted in slides with alcohol and examined at 400x magnifications. The percentage of each food item was obtained by a volumetric method, where the guts of chironomids were approximated to cylinders. The food contained in the guts was assumed as the $100 \%$ and the proportions of the different types of food were visualy estimated (Cheshire et al. 2005). To characterize the dietary habit of each genus (Gfh) we use the average values of the 10 analyzed individuals, following TrivinhoStrixino and Strixino (1993, 1998), Berg (1995), Schmid-Araya and Schmid (1995), Merritt et al. (1996), Correia and Trivinho-Strixino (1998), Trivinho-Strixino et al. (2000), Motta and Uieda (2005), Roque et al. (2005), Corbi and Trivinho-
Strixino (2008), Sanseverino and Nessimian (2001), Sonoda et al. (2009), Galizzi et al. (2012).

\subsubsection{Characterization of food usage per stream}

To characterize the importance of each food in each land use we multiplied the number of individuals of each genus by their Gfh and summed then for all genera of a stream.

With these values we tested the statistical difference of each item in different land uses. For this comparison we used a Kruskal-Wallis test.

\section{Results}

We collected and identified 807 larvae in reference streams, 1,119 in streams with sugar cane culture and 1,936 in pasture streams. The KruskalWallis test indicated no difference in abundance between the three groups of streams (Figure 2).

A total of 36 genera were identified, of which 27 in reference streams, 30 in the sugar cane culture and 33 in pastures. In pasture streams we observed the average richness of 19 genera, while in reference and sugar cane streams a richness of 13 taxa were found. The Kruskal-Wallis test indicated no difference between these groups for richness while the average was higher in pasture streams (Figure 2).

The genera Brundiniella, Constempellina, Fissimentum, Oukuriella and Phaenopsectra were exclusive of reference sites, while Tanypus, Rheocricotopus, Paracladius, Coelotanypus, Goeldichironomus and Harnischia were exclusive of pasture and Zavreliella and Stempellina of sugar cane culture.

The PERMANOVA indicated different taxonomic compositions between reference streams and impacted by sugar cane culture $(\mathrm{p}=0.034)$, as by pasture $(\mathrm{p}=0.015)$. This difference in composition can be visualized in the MDS analysis (Figure 3), but between the two groups of impacted streams we found no statistical difference $(\mathrm{p}=0.34)$.

SIMPER analysis (Table 2) showed the relative importance of each genus for the composition difference found in PERMANOVA. Among the Cerrado and sugar cane culture the high abundance of Paramectriocnemus, Ablabesmyia, Tanytarsus and Chironomus in sugar cane, contributed with $43.34 \%$ of the dissimilarity between the two environments. Among the Cerrado and pasture the genera that contributed were Tanytarsus, Polypedilum, Chironomus and Pentaneura, with $47.48 \%$ of the dissimilarity. The SIMPER analysis also indicated the relative importance of each genus in the faunal characterization of these streams (Figure 4). We 

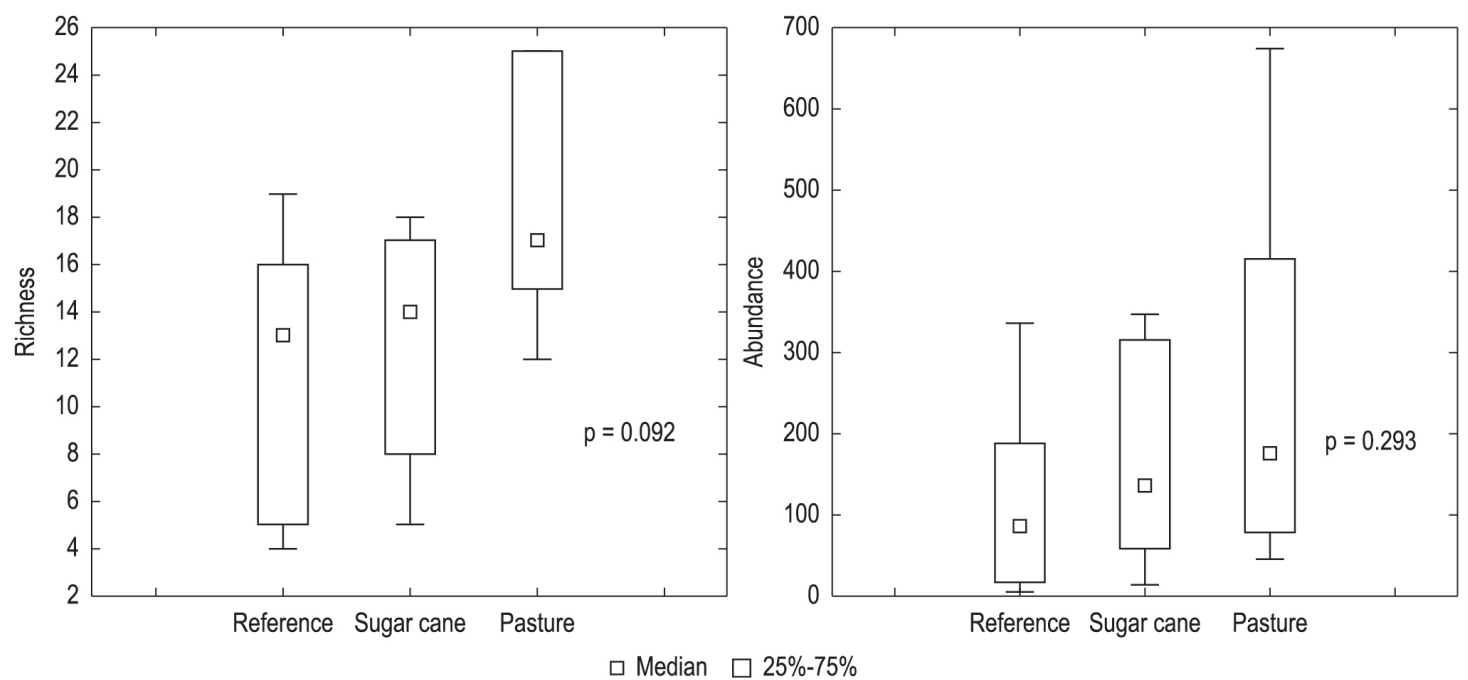

Figure 2. Box-and-whisker plots indicating $75 \%$ of the variation in the abundance and local richness of Chironomidae in reference and impacted streams. The p-value refers to the Kruskal-Wallis test.

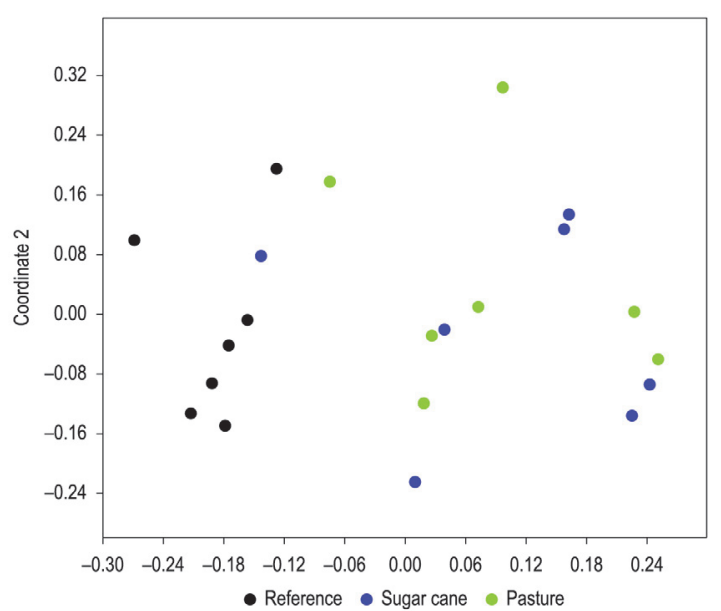

Figure 3. Multidimensional scaling showing the difference in taxonomic composition of Chironomidae among reference streams and impacted by sugar cane and pasture (Southeast Brazil).

highlight the abundance of Stenochironomus in reference streams. The relative importance of each food item per stream pointed out that the main item used in all streams are detritus, followed by microalgae, invertebrates, macroalgae and at last plant tissues. All genera presented more than one item in the diet (Figure 5).

The Kruskal-Wallis tests showed differences in food usage between reference Cerrado streams and sugar cane culture for plant tissues (Figure 6) and among streams of Cerrado and pasture for microalgae.

\section{Discussion}

Several studies report that streams located in watersheds under pasture land use have a high amount of dissolved organic matter from animal grazing (Buck et al., 2004; Allan, 2004; Matthaei et al., 2006). In our study, KruskalWallis test indicated no statistical differences, but the Box-and-Whiskers plots pointed out the high abundance of chironomids compared to reference and sugar cane streams. Other studies that found similar results (Buss et al., 2002; Niyogi et al., 2007; Sonoda et al., 2009) indicated that it was related to the increasing in the amount of detritus, main food item to most species (Merritt and Cummins, 1996).

The average taxonomic richness of pasture streams was higher than reference and sugar cane culture streams. Similar studies showed greater richness in forested streams, followed by sugar cane and pasture (Corbi and Trivinho-Strixino, 2008), while others found no statistical difference (Niyogi et al., 2007; Sonoda et al., 2009). Similar to ours results were reported by Lenat (1983), which indicated that moderately impacted sites with high organic matter content favor tolerant Chironomidae because possible competitors such as Ephemeroptera and Trichoptera have difficulties in colonizing such sites.

Another explanation is based on the fact that competition is weak in macroinvertebrates communities (Tokeshi, 1986; Tavares-Cromar and Williams, 1997; Heino et al., 2003; Saito and Mazão, 2012). In this case we consider that, in 
Table 2. Results of SIMPER analysis indicating the relative importance of each genus of Chironomidae to the dissimilarity between reference streams and impacted by sugar cane and pasture (Southeast Brazil).

\begin{tabular}{|c|c|c|c|c|c|c|c|}
\hline Taxon & $\begin{array}{c}\text { Cumulative } \\
\%\end{array}$ & Reference & $\begin{array}{l}\text { Sugar } \\
\text { cane }\end{array}$ & Taxon & $\begin{array}{c}\text { Cumulative } \\
\%\end{array}$ & Reference & Pasture \\
\hline Parametriocnemus & 17.75 & 0.286 & 45.3 & Tanytarsus & 16.9 & 10.9 & 67.3 \\
\hline Ablabesmyia & 27.35 & 13.1 & 18.9 & Polypedilum & 26.72 & 11.6 & 33.6 \\
\hline Tanytarsus & 36.44 & 10.9 & 20.4 & Chironomus & 35.82 & 7.71 & 30 \\
\hline Chironomus & 43.34 & 7.71 & 16.1 & Pentaneura & 41.67 & 13 & 10.6 \\
\hline Djalmabatista & 49.1 & 5.71 & 4 & Orthocladiinae_1 & 47.48 & 0 & 25.3 \\
\hline Cricotopus & 54.59 & 4 & 14.6 & Cricotopus & 52.77 & 4 & 16.6 \\
\hline Polypedilum & 59.57 & 11.6 & 4.43 & Ablabesmyia & 57.49 & 13.1 & 8.14 \\
\hline Pentaneura & 63.91 & 13 & 1.14 & Stenochironomus & 61.57 & 13.4 & 3.14 \\
\hline Stenochironomus & 68.21 & 13.4 & 0.143 & Rheotanytarsus & 65.61 & 0.143 & 13.6 \\
\hline Onconeura & 71.95 & 0.714 & 3.71 & Tanypus & 69.37 & 0 & 8 \\
\hline Rheotanytarsus & 75.52 & 0.143 & 8 & Cryptochironomus & 72.35 & 0.143 & 7.57 \\
\hline Labrundinia & 78.84 & 8.14 & 0 & Djalmabatista & 75 & 5.71 & 1.86 \\
\hline Lopescladius & 82.02 & 5.57 & 0.143 & Labrundinia & 77.66 & 8.14 & 2.57 \\
\hline Larsia & 84.97 & 2.86 & 4.57 & Parametriocnemus & 79.97 & 0.286 & 8 \\
\hline Endotribelos & 87.42 & 2.14 & 2.43 & Lopescladius & 82.15 & 5.57 & 0 \\
\hline Corynoneura & 89.05 & 3.29 & 0.429 & Larsia & 84.15 & 2.86 & 2.57 \\
\hline Parapentaneura & 90.65 & 2.57 & 0.429 & Pelomus & 85.84 & 2.43 & 4.43 \\
\hline Procladius & 92.23 & 0.286 & 3.14 & Dicrotendipes & 87.32 & 0 & 5.43 \\
\hline Pelomus & 93.74 & 2.43 & 0.429 & Parachironomus & 88.73 & 0 & 4.57 \\
\hline Cryptochironomus & 95.17 & 0.143 & 2.86 & Onconeura & 90 & 0.714 & 3.29 \\
\hline Clinotanypus & 96.26 & 0.143 & 2 & Corynoneura & 91.16 & 3.29 & 0.143 \\
\hline Pseudochironomini_1 & 97.01 & 2.57 & 0.286 & Endotribelos & 92.26 & 2.14 & 1.43 \\
\hline Riethia & 97.57 & 0.714 & 0.286 & Parapentaneura & 93.35 & 2.57 & 0.429 \\
\hline Nanocladius & 98.09 & 0.714 & 1 & Pseudochironomus & 94.4 & 0.857 & 3.57 \\
\hline Thienemanniella & 98.55 & 0 & 1.14 & Thienemanniella & 95.33 & 0 & 1.57 \\
\hline Paratendipes & 98.98 & 0.286 & 1 & Paratendipes & 96.15 & 0.286 & 2.29 \\
\hline Pseudochironomus & 99.31 & 0.857 & 0 & Clinotanypus & 96.91 & 0.143 & 1.43 \\
\hline Zavreliella & 99.51 & 0 & 0.571 & Pseudochironomini_1 & 97.63 & 2.57 & 1.14 \\
\hline Dicrotendipes & 99.69 & 0 & 0.286 & Fittkauimyia & 98.09 & 0 & 1.29 \\
\hline Fittkauimyia & 99.83 & 0 & 0.143 & Nanocladius & 98.52 & 0.714 & 1.29 \\
\hline Parachironomus & 99.93 & 0 & 0.286 & Procladius & 98.95 & 0.286 & 0.857 \\
\hline Paramerina & 100 & 0.286 & 0 & Riethia & 99.29 & 0.714 & 0 \\
\hline Rheocricotopus & 100 & 0 & 0 & Paramerina & 99.62 & 0.286 & 1 \\
\hline Paracladius & 100 & 0 & 0 & Paracladius & 99.82 & 0 & 0.714 \\
\hline Tanypus & 100 & 0 & 0 & Rheocricotopus & 100 & 0 & 1.14 \\
\hline Orthocladiinae_1 & 100 & 0 & 0 & Zavreliella & 100 & 0 & 0 \\
\hline
\end{tabular}

Cerrado

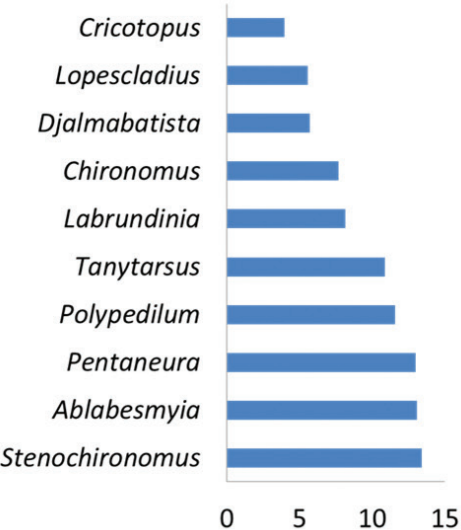

Sugar Cane

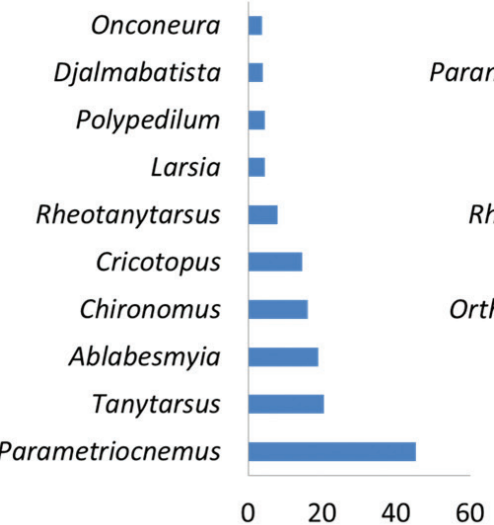

Pasture

Tanypus

Parametriocnemus

Ablabesmyia

Pentaneura

Rheotanytarsus

Cricotopus

Orthocladiinae_1

Chironomus

Polypedilum

Tanytarsus

$0 \quad 20 \quad 40 \quad 60 \quad 80$

Figure 4. Average relative abundance of genera of Chironomidae in reference Cerrado streams and impacted by sugar cane and pasture (Southeast Brazil). 
$\square$ detrites $\square$ microalgae $\square$ macroalgae $\square$ vegetaltissue $\square$ invertebrates

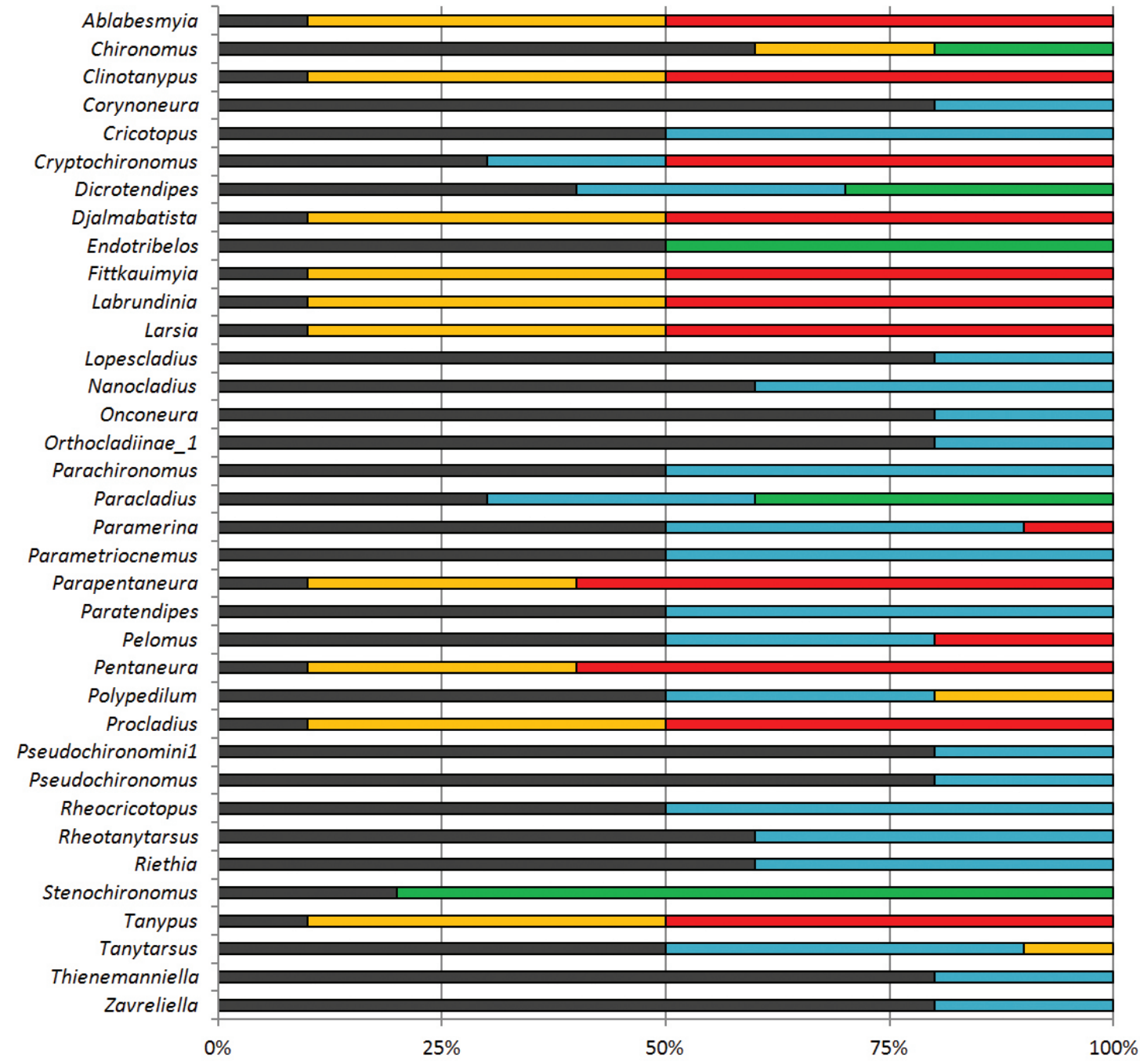

Figure 5. Percentage of food items in the diet of chironomid genera found in reference and impacted streams (Southeast Brazil).

systems with several species of high food affinity (niche overlap), the inter-specific competition needs to be weak; otherwise the competition would lead to competitive exclusions, decreasing the local richness (Tokeshi, 1986; Pinder, 1986; TavaresCromar and Williams, 1997; Tomanova et al., 2006). While the explanation of Lenat (1983) considers that competition decreases the richness of Chironomidae in reference streams, the other line of thinking consider that autoecological characteristics and environmental filters (e.g. muddy substrate preference rather than sandy) do not favor a rich community in reference streams. As our study did not aimed to find out which process increases or decreases richness we can not point out the role of competition in the studied streams. Regardless of the explanation, we reinforce Lenat (1983) suggestion that the use of Chironomidae richness as an environmental indicator is not indicated, because depending on the environmental changes, this can increase richness, declining only at very high levels of organic pollution (e.g. polluted urban streams).

Analyses of differences in taxonomic composition indicated that the conversion of native vegetation in anthropogenic land uses is a strong structurer in Chironomidae communities. In reference Cerrado streams some genera that were exclusive can be related to specific characteristics of these streams. Brundiniella has been associated with plant debris in forested streams (Trivinho-Strixino, 2011) and also observed large grains of sand in the digestive tract (Hudson et al., 1990), most common substrate in 


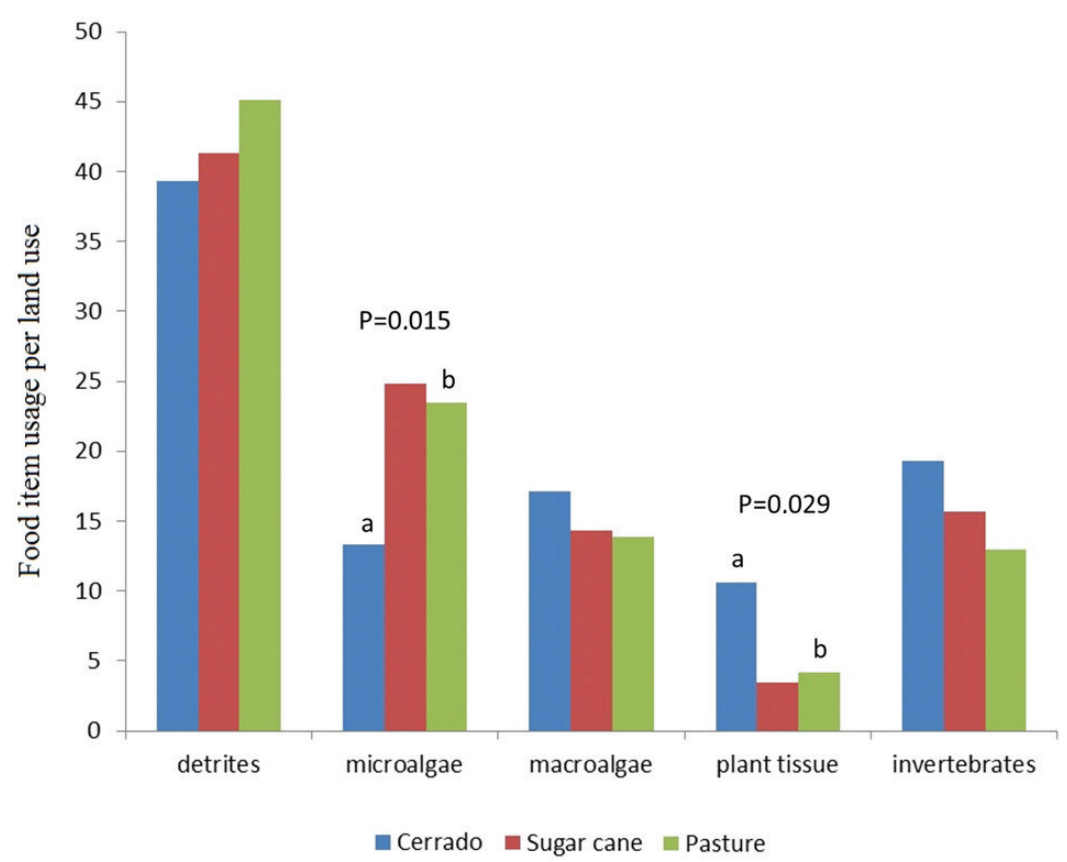

Figure 6. Characterization of food item usage per stream in reference Cerrado streams and impacted by sugar cane and pasture (Southeast Brazil). Letters "a" and "b" indicate statistically differences by the Kruskal-Wallis test.

Cerrado streams (Wantzen, 2003). Constempellina is dependent of sand because it builds tubes with sand grains (Hudson et al., 1990; Trivinho-Strixino, 2011). The genus Stenochironomus had the highest relative abundance and is directly related to the conservation of riparian vegetation. This miner genus have a mentum and body shape changed to feed of plant tissues, including stems, material dependent on riparian vegetation for deposition in stream (Trivinho-Strixino, 2011).

In streams of sugar cane culture the removal of riparian vegetation allows the growth of grasses and the invasion of sugar cane. These changes expand the channel and increase siltation, decreasing its physical complexity. In these sites the most abundant genera were Parametriocnemus, Ablabesmyia, Tanytarsus and Chironomus, genera considered common, tolerant and independent of specific substrates (Hudson et al., 1990; Trivinho-Strixino, 2011).

The conversion of natural areas into pasture directly impacts the water quality of streams, as the cattle increases the amount of organic matter in the catchment area and the lack of riparian vegetation causes the direct input in the streams. Furthermore, cattle physically degrade the streams, making them unstable in addition to polluted. In these streams the most representative genera were Tanytarsus, Polypedilum, Chironomus and Pentaneura. These genera are considered common and Polypedilum and Chironomus are remarkably tolerant to eutrophication and abundant in enriched areas. These two genera can produce large amounts of hemoglobin to store oxygen (Trivinho-Strixino, 2011) and booms are reported since 1913 (Johnson and Munger, 1930). Trivinho-Strixino (2011) argues that along the production of hemoglobin, the presence of abdominal tubules beyond the annals in Chironomus facilitates their survival in low oxygen environments because these extensions increase the surface of contact with water, facilitating gaseous exchange.

The detritus was the most important diet item for chironomid larvae, showing that Cerrado streams are rich in this type of food. Other authors have cited that most genera consume detritus as part of the diet and that this food item is critical in most food webs of tropical lotic systems (Pinder, 1986; Palmer et al., 1993; Woodward and Hildrew, 2002; Tomanova et al., 2006; Boyero et al., 2009).

The feeding habits of Chironomidae showed that all genera can feed of more than one item. Tomanova et al. (2006) analyzing the gut content of macroinvertebrates (except Chironomidae) from tropical streams also obtained the same pattern. According to Woodward and Hildrew (2002) feeding flexibility is an important adaptation because it reduces the overlap of niches and thus interspecific and intraspecific competition. This 
flexibility may have been critical to the survival and colonization of aquatic macroinvertebrates across the world (Tomanova et al., 2006).

Hieber and Gessner (2002) indicated that the leaf decomposition in the tropics is made primarily by microorganisms and not by invertebrates which supports our results, since even in streams with riparian forest the plant tissue was the least important food item. Nevertheless, the difference in the use of plant tissue between reference and impacted streams became clear, showing that the genus Stenochironomus is a component that can not be ignored in the decomposition process. The fact that we have only one abundant shredder genus corroborates the pattern found by Boyero et al. (2012), who found lower $\alpha$-diversity of shredders in tropical regions, indicating that in these regions the risk of losing key species of shredders is greater. The importance of detritus in the nutrition and the high abundance of Chironomidae in streams reinforce the importance of the family in ecosystem processes, transforming dead organic matter with low nutritional value in animal matter that can be used by other trophic levels (Cummins and Klug, 1979; Trivinho-Strixino, 2011).

We conclude that the conversion of reference areas in monocultures and pastures directly impact streams biodiversity by modifying the taxonomic structure of Chironomidae. For feeding patterns we found a mostly detritivorous diet, reinforcing the importance of this item in the diet of macroinvertebrates of tropical streams. The abundance of Stenochironomus indicates that this shredder genus has an important role in the processing of allochthonous material in forested streams.

\section{Acknowledgements}

We are thankful to Prof. Dr. Susana TrivinhoStrixino for helping with Chironomidae identification and to CNPq and FAPESP (2011/15077-3) for the graduate scholarship to VSS and the research scholarship to AAFG.

\section{References}

ALLAN, JD. 2004. Landscape and riverscape: the influence of alnd use on stream ecosystem. Annual Review of Ecology, Evolution and Systematics, vol. 35, p. 257-284. http://dx.doi.org/10.1146/annurev. ecolsys.35.120202.110122

ANDERSON, MJ. 2001. A new method for nonparametric multivariate analysis of variance. Austral Ecology, vol. 26, no. 1, p. 32-46.
BAILEY, RC., NORRIS, RH. and REYNOLDSON, TB. 2004. Bioassessment of Freshwater Ecosystems: Using the Reference Condition Approach. New York: Kluwer Academic Publishers.

BARBOUR, MT., GERRITSEN, J., GRIFFITH, GE., FRYDENBOURG, R., McCARRON, E., WHITE, JS. and BASTIAN, ML. 1996. A framework for biological criteria for Florida streams using benthic macroinvertebrates. Journal of North American Benthological Society, vol. 15, p. 185-211. http:// dx.doi.org/10.2307/1467948

BERG, MB. 1995. Larval food and feeding behaviour. In: ARMITAGE, PD., CRANSTON, OS. and PINDER, LCV., orgs. The Chironomidae: Biology and ecology of non-biting midges. Chapman \& Hall. $572 \mathrm{p}$.

BISPO, PC., OLIVEIRA, LG., BINI, LM. and SOUSA, KG. 2006. Ephemeroptera, Plecoptera and Trichoptera assemblages from rifles in mountain streams of Central Brazil: envorinmental fator influencing the distribution and abundance of immatures. Brazilian Journal of Biology, vol. 66, p. 611-622. PMid:16906293. http://dx.doi. org/10.1590/S1519-69842006000400005

BONADA, N., PRAT, N., RESH, VH. and STATZNER, B. 2006. Developments in aquatic insect biomonitoring: a comparative analysis of recent approaches. Annual Review Entomology, vol. 51, p. 495-523. PMid:16332221. http://dx.doi. org/10.1146/annurev.ento.51.110104.151124

BOYERO, L., RAMÍREZ, A., DUDGEON, D. and PEARSON, R. 2009. Are tropical stream really diferent? Journal of North American Benthological Society, vol. 28, no. 2, p. 397-403. http://dx.doi. org/10.1899/08-146.1

BUCK, O., NIYOGI, DK. and TOWNSEND, CR. 2004. Scale-dependence of land use effects on water quality of streams in agricultural catchments. Environmental Pollution, vol. 130, p. 287-299. PMid:15158041. http://dx.doi.org/10.1016/j. envpol.2003.10.018

BUSS, DF., BAPTISTA, DF., SILVEIRA, MP., NESSIMIAN, JL. and DORVILLÉ, LF. 2002. Influence of water chemistry and environmental degradation on macroinvertebrate assemblages in a river basin in south-east Brazil. Hydrobiologia, vol. 481, no. 1, p. 125-136.

CHESHIRE, K., BOYERO, L. and PEARSON, RG. 2005. Food webs in tropical Australian streams: shredders are not scarce. Freshwater Biology, vol. 50, no. 5, p. 748-769. http://dx.doi.org/10.1111/j.13652427.2005.01355.x

COFFMAN, WP. 1973. Energy flow in a woodland stream ecosystem: II. The taxonomic composition and phenology of the Chironomidae as determined by the collection of pupal exuviae. Archiv für Hydrobiologie, vol. 71, p. 281-322. 
CORBI, JJ. 2006. Influência de práticas de manejo de solo sobre os macroinvertebrados aquáticos de córregos: ênfase para o cultivo de cana-de-açúcar em áreas adjacentes. Biota Neotropica, vol. 6, no. 3.

CORBI, JJ. and TRIVINHO-STRIXINO, S. 2006. Influence of taxonomic resolution of stream macroinvertebrate communities on the evaluation of different land uses. Acta Limnologica Brasiliensia, vol. 18 , no. 4. p. 469-475.

CORBI, JJ. and TRIVINHO-STRIXINO, S. 2008. Relationship between sugar cane cultivation and stream macroinvertebrate communities. Brazilian Archives of Biology and Technology, vol. 51, no. 4, p. 569-579. http://dx.doi.org/10.1590/S151689132008000400015

CORREIA, LCS. and TRIVINHO-STRIXINO, S. 1998. Macroinvertebrados da rizosfera de Scirpus cubensis na lagoa do Infernão (Estação Ecológica de Jataí - SP): estrutura e função. Acta Limnologica Brasiliensia, vol. 10, p. 37-47.

COUCEIRO, SRM., HAMADA, N., FORSBERG, BR., PIMENTEL, TP. and LUZ, SLB. 2012. A macroinvertebrate multimetric index to evaluate the biological condition of streams in the Central Amazon region of Brazil. Ecological Indicators, vol. 18, 118-125. http://dx.doi.org/10.1016/j. ecolind.2011.11.001

CUMMINS, KW. and KLUG, MJ. 1979. Feeding ecology of stream invertebrates. Annual Review of Ecology and Systematics, vol. 10, p. 147-172. http:// dx.doi.org/10.1146/annurev.es.10.110179.001051

CUMMINS, KW., MERRITT, RW. and ANDRADE, P. 2005. The use of invertebrate functional groups to characterize ecosystem attributes in selected streams and rivers in southeast Brazil. Studies on Neotropical Fauna and Environment, vol. 40, p. 69-89. http:// dx.doi.org/10.1080/01650520400025720

DUDGEON, D. and WU, KK. 1999. Leaf litter in a tropical stream: food or substrate for macroinvertebrates? Archivies für Hydrobiologie, vol. 146 , no. 1 , p. 65-82.

DURIGAN, G., SIQUEIRA, MFD., ANTONIO, G. and CORREA, D. 2007. Threats to the cerrado remnants of the State of São Paulo. Brazilian Journal of Scientia Agricola, vol. 64, p. 355-363.

FERRINGTON JUNIOR, LC. 2008. Global diversity of non-biting midges (Chironomidae; Insecta-Diptera) in freshwater. In BALIAN, EV., LÉVÊQUE, C., SEGERS, H. and MARTENS, K, orgs. Freshwater Animal Diversity Assessment, Netherlands: Springer. $595 \mathrm{p}$.

GALIZZI, MC., ZILLI, F. and MARCHESE, M. 2012. Diet and functional feeding groups of Chironomidae (Diptera) in the Middle Paraná River floodplain (Argentina). Iheringia. Série Zoologia, vol. 102, no. 2, p. 117-121. http://dx.doi.org/10.1590/S007347212012000200001

HEINO, J., MUOTKA, T. and PAAVOLA, R. 2003. Determinants of macroinvertebrate diversity in headwater streams: regional and local influences. Journal of Animal Ecology, vol. 72, no. 3, p. 425-434. http://dx.doi.org/10.1046/j.13652656.2003.00711.x

HIEBER, M. and GESSNER, MO. 2002. Contribution of stream detrivores, fungi, and bacteria to leaf breakdown based on biomass estimates. Ecology, vol. 83, no. 4, p. 1026-1038. http://dx.doi. org/10.1890/0012-9658(2002)083[1026:COSDF $\mathrm{A}] 2.0 . \mathrm{CO} ; 2$

HUDSON, PL., LENAT, DR., CALDWELL, BA. and SMITH, D. 1990. Chironomidae of the southeastern United States: a checklist of species and notes on biology, distribution, and habitat. Fish and wildlife service Ann Arbor Mi Great Lakes Fishery Lab.

Instituto Brasileiro de Geografia e Estatística - IBGE. 2011. Anuário estatístico do Brasil. Rio de Janeiro: Ministério do Orçamento e Planejamento.

IRONS, JG., OSWOOD, MW., STOUT, RJ. and PRINGLE, CM. 1994. Latitudinal patterns in leaf litter breakdown: is temperature really important? Freshwater Biology, vol. 32, p. 401-411. http://dx.doi. org/10.1111/j.1365-2427.1994.tb01135.x

JOHNSON, MS. and MUNGER, F. 1930. Observations on excessive abundance of the midge Chironomus plumosus at Lake Pepin. Ecology, vol. 11, no. 1, p. 110-126. http://dx.doi.org/10.2307/1930784

LENAT, DR. 1983. Chironomid taxa richness: natural variation and use in pollution assessment. Freshwater Invertebrate Biology, p. 192-198.

MATTHAEI, CD., WELLER, F., KELLY, DW. and TOWNSEND, CR. 2006. Impacts of fine sediment addition to tussock, pasture, dairy and deer farming streams in New Zealand. Freshwater Biology, vol. 51, no. 11, p. 2154-2172. http://dx.doi.org/10.1111/ j.1365-2427.2006.01643.x

MERRITT, RW. and CUMMINS, KW., eds. 1996. An introduction to the aquatic insects of North America. Kendall Hunt. 862 p.

MERRITT, RW., CUMMINS, KW. and RESH, VH. 1996. Design of aquatic insect studies: collecting, sampling and rearing procedures. In MERRITT, RW. and CUMMINS, KW., orgs. An introduction to the aquatic insects of North America. Iowa: KendallHunt. 862 p.

MOTTA, RL. and UIEDA, VS. 2005. Food web structure in a tropical stream ecosystem. Austral Ecology, vol. 30, no. 1, p. 58-73. http://dx.doi. org/10.1111/j.1442-9993.2005.01424.x

MYERS, N., MITTERMEIER, RA., MITTERMEIER, CG., FONSECA, GA. and KENT, J. 2000. 
Biodiversity hotspots for conservation priorities. Nature, vol. 403, no. 8, p. 53-858.

NIYOGI, DK., KOREN, M., ARBUCKLE, CJ. and TOWNSEND, CR. 2007. Stream communities along a catchment land-use gradient: subsidystress responses to pastoral development. Environmental management, vol. 39, no. 2, p. 213225. PMid:17160511. http://dx.doi.org/10.1007/ s00267-005-0310-3

PALMER, C., O'KEEFFE, JAY. and PALMER, A. 1993. Macroinvertebrate functional feeding groups in the middle and lower reaches of the Buffalo River, eastern Cape, South Africa. II. Functional morphology and behaviour. Freshwater Biology, vol. 29, no. 3, p. 455462. http://dx.doi.org/10.1111/j.1365-2427.1993. tb00779.x

PINDER, LCV. 1986. Biology of freshwater Chironomidae. Annual Review of Entomology, vol. 31, no. 1, p. 1-23. http://dx.doi.org/10.1146/annurev. en.31.010186.000245

POFF, NL., OLDEN, JD., VIEIRA, NK., FINN, DS., SIMMONS, MP. and KONDRATIEFF, BC. 2006. Functional trait niches of North American lotic insects: traits-based ecological applications in light of phylogenetic relationships. Journal of the North American Benthological Society, vol. 25, no. 4, p. 730-755. http://dx.doi.org/10.1899/08873593(2006)025[0730:FTNONA]2.0.CO;2

RABENI, CF. and WANG, N. 2001. Bioassessment of streams using macroinvertebrates: are the Chironomidae necessary? Environmental Monitoring and Assessment, vol. 71, p. 177-185. PMid:11686199. http://dx.doi.org/10.1023/A:1017523115381

ROQUE, FO., SIQUEIRA, T. and TRIVINHOSTRIXINO, S. 2005. Occurrence of chironomid larvae living inside fallen-fruits in Atlantic Forest streams, Brasil. Entomología y Vectores, vol. 12, no. 2, p. $275-282$.

ROSENBERG, DM. 1992. Freshwater biomonitoring and Chironomidae. Netherlands Journal of Aquatic Ecology, vol. 26, no. 2, p. 101-122.

ROSENBERG, DM. and RESH, VH. 1993. Freshwater biomonitoring and benthic invertebrates. New York: Chapman and Hall. 504 p.

SAITO, VS. and MAZÃO, GR. 2012. Macroinvertebrates under stochastic hydrological disturbance in Cerrado streams of Central Brazil. Iheringia. Série Zoologia, vol. 102, no. 4, p. 448-452. http://dx.doi. org/10.1590/S0073-47212012005000008

SANSEVERINO, AM. and NESSIMIAN, JL. 2001. Hábitats de larvas de Chironomidae (Insecta, Diptera) em riachos de Mata Atlântica no Estado do Rio de Janeiro. Acta Limnologica Brasiliensia, vol. 13, no. 1, p. 29-38.

SCHMID-ARAYA, JM. and SCHMID, PE. 1995. Preliminary results on diet of stream invertebrate species: the meiofaunal assemblages. Jahresbericht Biologische Station Lunz, vol. 15, p. 23-31.
SILVA, JMC. and BATES, JM. 2002. Biogeographic patterns and conservation in the South American Cerrado: a Tropical Savanna Hotspot. BioScience, vol. 52, p. 225-233. http://dx.doi.org/10.1641/00063568(2002)052[0225:BPACIT]2.0.CO;2

SONODA, KC., MATTHAEI, CD. and TRIVINHOSTRIXINO, S. 2009. Contrasting land uses affect Chironomidae communities in two Brazilian rivers. Fundamental and Applied Limnology/Archiv für Hydrobiologie, vol. 174, no. 2, p. 173-184. http:// dx.doi.org/10.1127/1863-9135/2009/0174-0173

STOTT, P. 1991. Recent trends in the ecology and management of the world's savanna formations. Progresses in Physical Geography, vol. 15, p. 18-28. http://dx.doi.org/10.1177/030913339101500102

STODDARD, JL., LARSEN, DP., HAWKINS, CP., JOHNSON, RK. and NORRIS, RH. 2006. Setting expectations for the Ecological condition of streams: the concept for reference condition. Ecological Applications, vol. 16, p. 1267-1276. http://dx.doi. org/10.1890/1051-0761(2006)016[1267:SEFTE C]2.0.CO;2

SURIANO, MT., FONSECA-GESSNER, AA., ROQUE, FO. and FROEHLICH, CG. 2010. Choice of macroinvertebrate metrics to evaluate stream conditions in Atlantic Forest, Brazil. Enviromental Monitoring and Assessment, vol. 175, p. 87-101. PMid:20461547.

TAVARES-CROMAR, AF. and WILLIAMS, DD. 1997. Dietary overlap and coexistence of chironomid larvae in a detritus-based stream. Hydrobiologia, vol. 354, no. 1-3, p. 67-81.

TETRATECH. 2000. A Stream Condition Index for West Virginia Wadeable Streams. Unpublished report.. U.S. EPA Region 3 Environmental Services Division and Office of Water, Wheeling.

TOKESHI, M. 1986. Resource utilization, overlap and temporal community dynamics: a null model analysis of an epiphytic chironomid community. Journal of Animal Ecology, p. 491-506. http://dx.doi. org/10.2307/4733

TOMANOVA, S., GOITIA, E. and HELEŠIC, J. 2006. Trophic Levels and Functional Feeding Groups of Macroinvertebrates in Neotropical Streams. Hydrobiologia, vol. 556, p. 251-264. http://dx.doi. org/10.1007/s10750-005-1255-5

TRIVINHO-STRIXINO, S. 2011. Larvas de Chironomidae. Guia de Identificação. São Carlos: Departamento Hidrobiologia. Laboratório de Entomologia Aquática/UFSCAR. 371 p.

TRIVINHO-STRIXINO, S., CORREIA, LCS. and SONODA, K. 2000. Phytophilous Chironomidae (Diptera) and other macroinvertebrates in the oxbow Infernão Lake (Jataí Ecological Station, Luiz Antônio, SP, Brazil). Revista Brasileira de Biologia, vol. 60 , no. 3. p. 527-535. 
TRIVINHO-STRIXINO, S. and STRIXINO, G. 1993. Estrutura de comunidades de insetos aquáticos associados à Pontederia lanceolata Nuttal. Revista Brasileira de Biologia, vol. 53, p. 103-111.

TRIVINHO-STRIXINO, S. and STRIXINO, G. 1998. Chironomidae (Diptera) associados a troncos de árvores submersos. Revista Brasileira de Entomologia, vol. 41, p. 173-178.

WANTZEN, KM. 2003. Cerrado streamscharacteristics of a threatened freshwater ecosystem type on the Tertiary Shields of Central South America. Amazoniana, vol. 17, p. 485-502.
WOODWARD, G. and HILDREW, AG. 2002. Bodysize determinants of niche overlap and intraguild predation within a complex food web. Journal of Animal Ecology, vol. 71, no. 6, p. 1063-1074. http:// dx.doi.org/10.1046/j.1365-2656.2002.00669.x

YULE, CM., LEONG, MY., LIEW, KC., RATNARAJAH, L., SCHMIDT, K., WONG, HM., PEARSON, RG. and BOYERO, L. 2009. Shredders in Malaysia: abundance and richness are higher in cool upland tropical streams. Journal of the North American Benthological Society, vol. 28, no. 2, p. 404-415. http://dx.doi.org/10.1899/07-161.1

Received: 14 August 2013 Accepted: 13 May 2014 